\title{
Enveloping curves for the highest floods of river basins in India
}

\begin{abstract}
There are many small as well as large river basins in India. These basins are subjected to flooding in the rainy season when they receive heavy and wide spread rainfall Envelope curves, obtained by plotting the highest observed floods of various rivers versus their drainage areas, are useful for designing dams and flood control structures on the rivers in those areas where flood records or hydro-meteorological data are not sufficient. In this paper, envelope curves of the highest recorded floods for each of the 3 meteorologically homogeneous regions of India are presented for their use in estimating the maximum probable flood discharge that can be expected in the river basin of a certain size.
\end{abstract}

Volume I Issue 3 - 2017

\author{
Rakhecha PR,' Singh VP2 \\ 'Indian Institute of Tropical Meteorology, India \\ ${ }^{2}$ Department of Biological \& Agricultural Engineering, Texas A \& \\ M, University, USA
}

Correspondence: Rakhecha PR, Indian Institute of Tropica Meteorology, India, Email rakhechapukhraj@gmail.com

Received: August 15, 2017 | Published: September 22, 2017

Keywords: Enveloping curve, Design flood, Rainstorm, Meteorology, Maximum probable flood

\section{Introduction}

About 80 to 90 percent of the annual rainfall over most parts of India falls during the southwest monsoon season between June and September. ${ }^{1,2}$ Dams on the rivers are built in order to store the excess water for its use throughout the year. There are over 3000 dams in India and more new dams are being constructed for securing water supply for the growing population. ${ }^{3}$ When a dam is constructed across a river, a spillway or spillway system is built as a safety feature to pass the greatest flood that can occur from heavy rainfall over the drainage basin. The magnitude of this greatest flood that could arise from heavy rainfall at the dam site is called the spillway design flood. Design floods for a basin are estimated by using long period stream flow or rainfall records using statistical or hydro-meteorological methods. ${ }^{4}$ However, in some river basins where major dams are envisaged long term stream flow or rainfall data may often be inadequate. For basins catchments with sparse or no data, the dam design becomes a more difficult problem. For such a situation, hydrologists have developed methods for transferring information on stream flow/rainfall data from a meteorologically and topographically analogous region to the location at which the design flood value is required. A study towards the development of a method of utilizing the flood discharge data available for a number of catchments led to the hypothesis that the maximum flood per unit area experienced during a rainstorm in one catchment is quite likely to be experienced in a nearby catchment of similar meteorological conditions. ${ }^{5}$ Based on this hypothesis, observed maximum flood discharges from a number of catchments having similar topographical and meteorological conditions were plotted on log-log scale against drainage areas and the plotted points were then enveloped by a smooth curve. Enveloping curves thus obtained have been found to be very useful in estimating the maximum flood discharge value that can be expected in the river basin of a certain size. If equations are fitted to these enveloping curves, they provide empirical flood formulae in the form of $Q=k A^{n}$ where A is the drainage area, $\mathrm{Q}$ is discharge, $\mathrm{n}$ is exponent and $\mathrm{k}$ is a constant. Both $\mathrm{n}$ and $\mathrm{k}$ can be considered as fitting parameters.

\section{Enveloping curves for river basins in India}

The first studies for determining the enveloping curves of maximum floods for river basins in India were carried out by Kanwar Sain \& Karpov in 1967 as reported in, ${ }^{6}$ by utilizing the flood discharge data available for a number of river basins. Two curves, one for the basins of northern \& central Indian rivers and other for southern Indian rivers were developed. The envelope curves for India determined by Kanwar Sain \& Karpov using data up to 1967 are given in Figure 1.These envelope curves have been used as guidance for estimating the design flood values for many water resources projects in India, like Nagarjunsagar in Andhra Pradesh, Matatila in Uttar Pradesh and Deonur in Karnataka, etc. It is well known that the maximum flood discharge value from a basin of a certain size may change with time because a still higher flood discharge may occur at some time in the future. For example, according to Kale, ${ }^{7}$ the maximum flood discharge of $42475 \mathrm{~m}^{3} / \mathrm{s}$ for a drainage area of $62225 \mathrm{~km}^{2}$ on the Tapi River in the year 1968, the maximum flood discharge of $69400 \mathrm{~m}^{3} / \mathrm{s}$ for a drainage area of $88000 \mathrm{~km}^{2}$ on the Narmada River in the year 1970 $\&$ the maximum flood discharge of $44827 \mathrm{~m}^{3} / \mathrm{s}$ for a drainage area of $127000 \mathrm{~km}^{2}$ on the Mahanadi River in the year 1982 have been higher than those recorded before the year 1967. Also, Rakhecha ${ }^{8}$ found that the maximum flood discharge of $16307 \mathrm{~m}^{3} / \mathrm{s}$ for a drainage area of $1930 \mathrm{~km}^{2}$ was the highest on the Machhu River in the year 1979. It is seen that the recent floods lie above the enveloping curves of Kanwar Sain \& Karpov. It is therefore concluded that the flood observations after the 1967 have significantly altered the envelope curves. As such, the existing envelope curves of India are old as compared with the new data published in numerous scientific papers and reports, ${ }^{9}$ as also pointed out above. Thus, there is a need for a fresh study of enveloping curves for the highest floods in India so that they can be used for estimating the design floods for the dams that may be constructed now and in the future.

\section{Rivers in India}

There are numerous small as well as great rivers in India that flow in various parts of the country (Figure 2). These rivers can be classified into two major groups. The first group consists of all the great rivers and their tributaries of the Himalayan region in the northern part of India and the second consist of the rivers of the central and peninsular India. The main Himalayan Rivers are the Indus, Ganga and the Brahmaputra. These Rivers are both snow fed and rain 
fed and therefore are perennial and carry large amounts of water and sediments. The combined drainage area of the Ganga River basin and its tributaries (Yamuna, Son, Betwa, Chambal, Damodar, Gandak, Ghagra, Gomati, Mahakali, Kosi, and Ramganga) totals about $861404 \mathrm{~km}^{2}$ which accounts for 25 per cent of the area of India. The basin covers several states of India. In summer monsoon season their water levels are very high and they have a long flood season lasting from June to September. The major dams and barrages on the Ganga are Tehri dam, Vishnuprayag dam, Bhimgauda barrage, Pashulok barrage, Bijnor barrage, Narora barrage, Kanpur barrage, and Farakka barrage. The rivers in central and southern India are the Mahanadi, Subarnarekha, Tapi, Narmada, Godavari, Krishna, Mahi, Sabarmati, Cauvery and the Pennar. These rivers depend on rainfall for water and therefore are non-perennial. There are numerous coastal rivers and of these rivers, especially on the west coast are short in length and have limited catchment areas. All the above rivers are subjected to flooding during the southwest monsoon season due to severe rainstorms that occur over their catchments. Table 1 gives some of the basic hydrological data of the 14 major river basins in India. The method of enveloping curve is a regional analysis method which considers that there is a unique relationship between the maximum flood and the basin area in a region that is meteorologically homogeneous. It is therefore important first to determine the meteorologically homogeneous regions for which envelope curves of maximum floods can be developed.

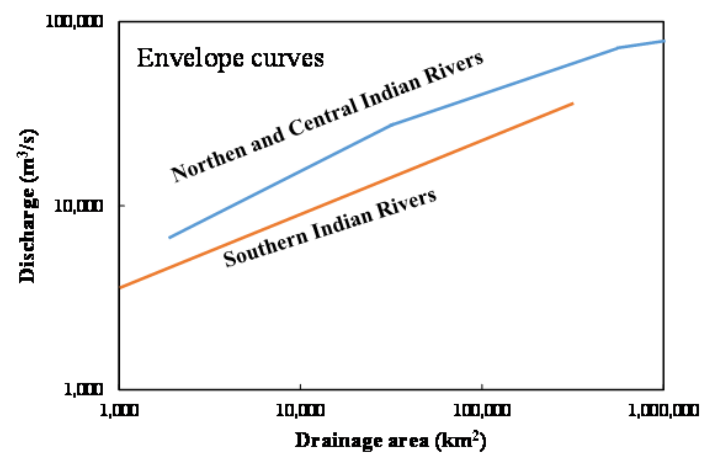

Figure I Envelope curves (after Kanwar Sain \& Karpov, 1967).

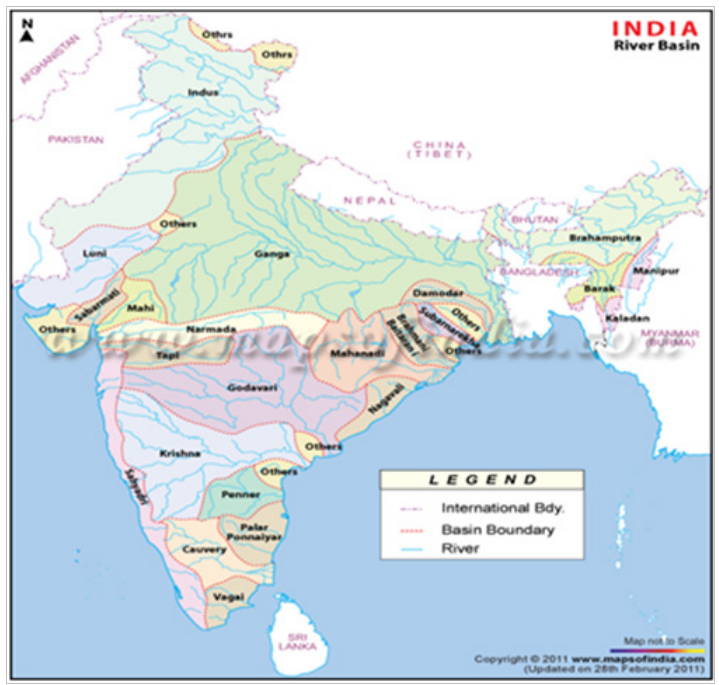

Figure 2 Major river systems in India.
Table I Basic hydrological data of the major rivers in India ${ }^{18}$

\begin{tabular}{lllll}
\hline S/No. & River & $\begin{array}{l}\text { Length } \\
(\mathbf{k m})\end{array}$ & $\begin{array}{l}\text { Drainage } \\
\text { area }\left(\mathbf{K m}^{2}\right)\end{array}$ & $\begin{array}{l}\text { Average annual } \\
\text { runoff }\left(\mathbf{k m}^{3}\right)\end{array}$ \\
\hline I & Indus & 2880 & 321290 & 73.3 \\
2 & Ganga & 2525 & 861404 & 525 \\
3 & Brahmaputra & 2900 & 187110 & 537.3 \\
4 & Sabarmati & 300 & 21674 & 3.8 \\
5 & Mahi & 533 & 34842 & 11 \\
6 & Narmada & 1312 & 98796 & 45.6 \\
7 & Tapi & 724 & 65145 & 14.9 \\
8 & Subarnarkha & 395 & 19300 & 12.4 \\
9 & Brahmani & 800 & 39033 & 28.5 \\
10 & Mahanadi & 857 & 141600 & 66.9 \\
11 & Godavari & 1465 & 312812 & 110.6 \\
12 & Krishna & 1401 & 258948 & 78.1 \\
13 & Pennar & 597 & 55213 & 6.3 \\
14 & Cauvary & 800 & 87900 & 21.4 \\
\hline
\end{tabular}

\section{Meteorological homogeneous regions}

Severe rainstorms (heavy rainfalls) are the main cause of frequent floods on the Indian rivers. For the estimation of flood from a rainstorm in a catchment when the sample of severe rainstorms within the catchment is not adequate, the record is increased by transferring major storms from a meteorologically homogeneous or analogous region to the location for which the flood value is required. Two regions are said to be meteorologically homogeneous if they have

1. Similar features of climate (mean annual temperature, mean annual rainfall, direction of prevailing winds, etc.)

2. Identical topographic features

3. The same moisture source

4. Occurrence of the same type of rainstorms. ${ }^{10-12}$

Apparently, factors that are responsible in setting meteorological homogeneous regions involve a detailed study of the climatology of spatial distribution of severe rainstorms. Therefore, the spatial distribution and climatological characteristics of severe rainstorms offer much promise in the determination of broad meteorologically homogeneous regions.

Occurrence of severe rainstorms in India: Severe rainstorms or heavy rainfall in India which may last for a period of 3to4 days are generally associated with the movement of cyclonic disturbances across the country that forms over the Bay of Bengal \& the Arabian Sea. The rainstorm area may be as large as $400,000 \mathrm{~km}^{2}$ and point rainfalls may vary between 40 and $80 \mathrm{~cm}$ in 24 hours $^{13}$ Such rainstorms are the main cause of high rainfall and severe floods in the Indian rivers. The meteorological factors which influence the location of a rainstorm have been described in some detail by. ${ }^{14}$ These factors important to the occurrence and distribution of severe rainstorms as described by them are summarized here. Normally during the summer monsoon season (June through September) the cyclonic disturbances 
(mainly depressions with associated winds 20-33 knots) form at the head of the Bay of Bengal to the north of $18^{\circ} \mathrm{N}$ and travel northwesterly across India. The disturbances after travelling a long distance normally become weak due to the decrease of moisture and therefore merge with the low pressure area over northwest India. These disturbances normally produce heavy rainstorms in the region east of $80^{\circ} \mathrm{E}$ (Figure 3). Sometimes, the disturbances after arriving in central India (about $80^{\circ} \mathrm{E}$ ), become more intense owing to the additional supply of moisture from the Arabian Sea and then they move in the north easterly direction. In general, such disturbances produce severe rainstorms in the region west of $80^{\circ} \mathrm{E}$ (Figure 3). The disturbances which form over the south Bay of Bengal during the pre and post monsoon months produce heavy rainstorms over the southern parts of India. ${ }^{15-17}$ showed that the following 13 rainstorms produced the largest areal rain depths in India.
a. September $17-18,1880$
b. September $20-22,1990$
c. September $19-21,1926$
d. July 26-28, 1927
e. July $28-30,1927$
f. July $1-3,1941$
g. May $17-19,1943$
h. October 3-5, 1955
i. October 1-3, 1961
j. September 28-30, 1964
k. July $13-15,1965$
1. July $18-21,1981$
m. August 28-30, 1982

The rainstorm durations ranged from 2 to 3 days and were associated with the depressions from the Bay of Bengal. The rain centers of these storms are shown in Figure 3.

Delineation of meteorological homogeneous regions: The spatial distribution of rainstorms with alike meteorological characteristics as discussed above are used as a guide in delineating the meteorologically homogeneous regions for developing the enveloping curves of flood data. It is seen that the rainstorms of September 1880, July 1927, July 1941, and August 1981 occurred far inside the country although the associated disturbances originated in the Bay of Bengal. This was mainly due to the additional moisture supply from the Arabian Sea monsoon currents. Such storms which occur after significant modification from the Arabian Sea currents must form a separate group from those storms which occur without any modification. After consideration of the spatial distribution and meteorological characteristics of the rainstorms and following, ${ }^{14}$ India is divided into three meteorologically homogeneous regions viz., west of $80^{\circ} \mathrm{E}$ and north of $18^{\circ} \mathrm{N}$; east of $80^{\circ} \mathrm{E}$;north of $18^{\circ} \mathrm{N}$; south of $18^{\circ} \mathrm{N}$ as shown in Figure 3. The one day average areal rain depths estimated from these rainstorms in their respective regions are given in Table 2 for comparison and to establish the support of dividing the country into three regions. Table 2 shows that the one day average areal rain depths in the three different regions from their respective rainstorms vary between wide limits. The areal rainfall values from the rainstorms in the south of $18^{\circ} \mathrm{N}$ are lower than those of the northern regions.

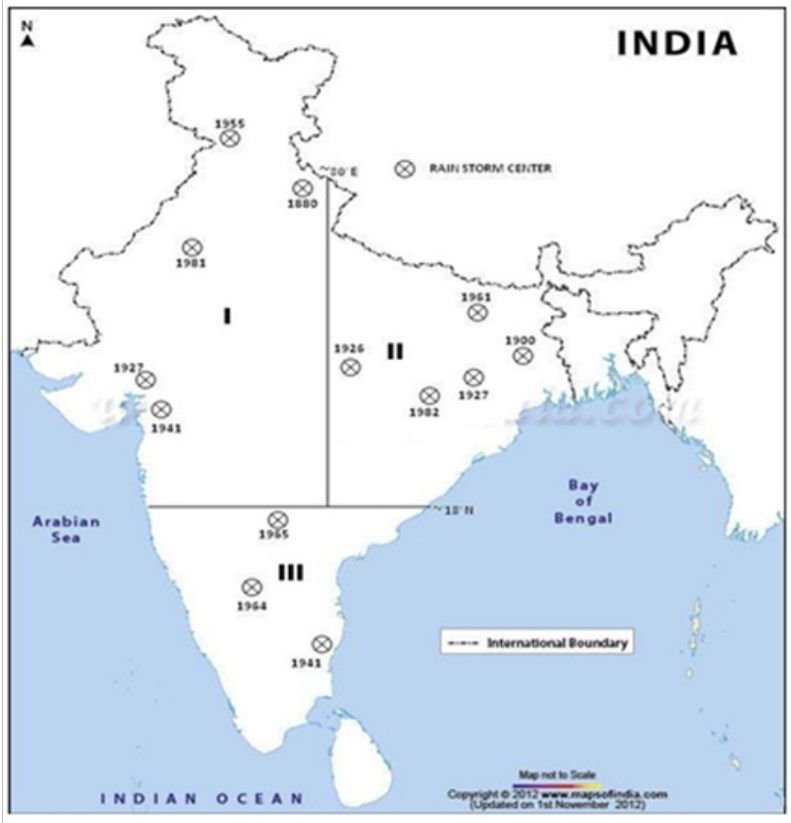

Figure 3 Locations of rainstorms \& the three meteorological homogeneous regions.

Table 2 One day average areal rain depths $(\mathrm{cm})$ of the most severe rainstorms in different regions

\begin{tabular}{|c|c|c|c|c|c|c|c|c|}
\hline \multirow[t]{2}{*}{ S/No } & \multirow[t]{2}{*}{ Regions } & \multirow[t]{2}{*}{ No. of storms } & \multicolumn{6}{|l|}{ Areas in sq.km } \\
\hline & & & 10 & 500 & 1000 & 5000 & 10000 & 20000 \\
\hline 1 & West of $800 \mathrm{E} \&$ north of $180 \mathrm{~N}$ & 5 & 71 & 67 & 64 & 52 & 44 & 35 \\
\hline II & East of $800 \mathrm{E} \&$ north of $180 \mathrm{~N}$ & 5 & 45 & 44 & 43 & 38 & 33 & 27 \\
\hline III & South of $180 \mathrm{~N}$ & 3 & 39 & 36 & 33 & 25 & 22 & 19 \\
\hline
\end{tabular}

\section{Floods in rivers of homogeneous meteorological regions of India}

Flood discharges in Indian rivers at various gauging sites are available since about 1950 in numerous scientific papers and reports. $^{7-11}$ By pooling together all the information obtained from various publications and reports, the largest flood discharges at sites on major rivers of the three different homogeneous meteorological regions are listed in Table 3. The largest flood discharges on record of rivers in the regions east of $80^{\circ} \mathrm{E}$ and north of $18^{\circ} \mathrm{N}$, west of $80^{\circ} \mathrm{E}$ and north of $18^{\circ} \mathrm{N}$ and south of $18^{\circ} \mathrm{N}$ range between 1170 and $73,900 \mathrm{~m}^{3} / \mathrm{s}$, 1177 and $69,400 \mathrm{~m}^{3} / \mathrm{s}$ and 13450 and $78,800 \mathrm{~m}^{3} / \mathrm{s}$ respectively. 
Table 3 Highest recorded floods on the river basins located in different regions of India (A) River catchments in the region located east of $80^{\circ} \mathrm{E}$ and north of $18^{\circ} \mathrm{N}$; (B) River catchments in the region located west of $80^{\circ} \mathrm{E}$ and north of $18^{\circ} \mathrm{N}$; (C) River catchments in the region located south of $18^{\circ} \mathrm{N}$

\begin{tabular}{|c|c|c|c|c|c|c|}
\hline S/No. & River basin & Stream & Site & Area $\left(\mathbf{k m}^{2}\right)$ & Flood $\left(\mathrm{m}^{3} / \mathrm{s}\right)$ & Year \\
\hline 1 & Brahamaputra & Gish & - & 133 & 1,170 & Jul-68 \\
\hline 2 & Subarnarekha & Ramiala & Ramiala & 328 & 3,108 & Sept. 1983 \\
\hline 3 & Ganga & Tons & Meja Rd & 17,400 & 10,800 & Jul-7I \\
\hline 4 & Brahmani & Brahmani & Bolani & 18,070 & 13,570 & Aug. 1974 \\
\hline 5 & Mahanadi & Mahanadi & Kantamel & 19,600 & 15,400 & Sept. 1977 \\
\hline 6 & Ganga & Damodar & Rhondia & 19,900 & 18,100 & Aug. 1935 \\
\hline 7 & Mahanadi & Tel & - & 25,045 & 33,762 & 2008 \\
\hline 8 & Ganga & Betwa & Sahijna & 43,870 & 43,800 & Jul-7I \\
\hline 9 & Ganga & Kosi & Barakshetra & 59,052 & 23,085 & Aug. 1924 \\
\hline 10 & Ganga & Sone & Kolewar & 67,878 & 36,800 & Jul-7| \\
\hline II & Mahanadi & Mahanadi & Naraj & 127,000 & 44,827 & Aug. 1982 \\
\hline 12 & Brahamaputra & Brahamaputra & Pandu & 404,000 & 72,700 & Aug. 1962 \\
\hline 13 & Ganga & Ganga & Farrakka & 935,000 & 72,900 & Aug. 1954 \\
\hline S/No. & River Basin & Stream & Site & Area $\left(\mathbf{k m}^{2}\right)$ & Flood $\left(\mathrm{m}^{3} / \mathrm{s}\right)$ & Year \\
\hline 1 & Mahi & Kharm & Patadungri & 212 & I, I77 & - \\
\hline 2 & Kutch & Moj & Moj & 440 & 3,981 & - \\
\hline 3 & Kutch & Brahmani & Brahmani & 699 & 5,450 & - \\
\hline 4 & Kutch & Machhu & Machhu-I & 735 & 9,340 & Aug. 1979 \\
\hline 5 & Kutch & Damanganga & Damanganga & 1,813 & 12,900 & - \\
\hline 6 & Kutch & Machhu & Machhu-2 & 1,930 & 16,307 & Aug. 1979 \\
\hline 7 & Sabarmati & Banas & Dantiwada & 2,862 & 11,950 & Aug. 1973 \\
\hline 8 & Mahi & Mahi & Chandangarh & 4,320 & 8,160 & Jun-77 \\
\hline 9 & Sabarmati & Sabarmati & Dharoi & 5,540 & 14,150 & Aug. 1973 \\
\hline 10 & Indus & Ravi & Madhopur & 6,087 & 26,052 & Sept. 1988 \\
\hline 11 & Ganga & Yamuna & Tajewala & 11,059 & 15,947 & Sept. 1947 \\
\hline 12 & Ganga & Ganga & Rishikest & 21,800 & 16,000 & Aug. 1924 \\
\hline 13 & Ganga & Chambal & Jhalawar & 22,584 & 37,000 & Aug. 1969 \\
\hline 14 & Mahi & Mahi & Kadana & 25,491 & 33,000 & - \\
\hline 15 & Tapi & Tapi & Ukai & 62,225 & 42,475 & Aug. 1968 \\
\hline 16 & Narmada & Narmada & Garudeshwar & 88,000 & 69,400 & Sept. 1970 \\
\hline S/No. & River Basin & Stream & Site & Area $\left(\mathbf{k m}^{2}\right)$ & Flood $\left(\mathrm{m}^{3} / \mathrm{s}\right)$ & Year \\
\hline I & Godavari & Kadam & Kadam & 2,590 & 13,450 & Aug. 1958 \\
\hline 2 & Godavari & Indravati & Barthagudam & 40,000 & 24,860 & Aug. 1976 \\
\hline 3 & Krishna & Krishna & Vijayawada & 257,000 & 39,000 & 3-Jul \\
\hline 4 & Godavari & Godavari & Dowlaishwaram & 309,000 & 99300 & Aug. 1986 \\
\hline
\end{tabular}




\section{Enveloping curves of the highest floods for the three regions}

The studies towards the development of a more rational method of utilizing the flood data available for a number of basins led to the hypothesis that the maximum flood per unit area experienced in one basin is quite likely to be experienced in a nearby basin in the same region possessing similar meteorological characteristics. Based on this hypothesis, observed flood discharges along with their catchment areas ranging for about 100 to about $10^{6} \mathrm{~km}^{2}$ for each of the above 3 meteorologically homogeneous zones were used to develop enveloping curves. For this purpose, the observed flood peak data for a number of catchments in each of the three homogeneous regions were plotted on a log-log paper as flood peak versus catchment area. The plotted points are shown in Figure 4 as scattered points. An enveloping curve encompassing all the plotted points for each of the three meteorologically homogeneous zones is then drawn. The enveloping curves for the 3 meteorological zones are shown in Figure 4. The enveloping curve is an upper limit for the floods, and the flood discharges at some sites lie considerably below the curve. The enveloping curves thus obtained are very useful in getting a quick estimation of peak flood value that can be expected in the river catchment of a certain size. Envelope curves of the rivers in the region located east of $80^{\circ} \mathrm{E}$ and north of $18^{\circ} \mathrm{N}$ and rivers in the region located west of $80^{\circ} \mathrm{E}$ and north of $18^{\circ} \mathrm{N}$ are close to each other for catchments of size less than $1,000 \mathrm{~km}^{2}$ in area. The curve of the other region located south of $18^{0} \mathrm{~N}$ is rather different. A steep increase is seen for catchments of size greater than $17,000 \mathrm{~km}^{2}$ in the region located west of $80^{\circ} \mathrm{E}$ and north of $18^{\circ} \mathrm{N}$. It may be noted that the floods being plotted are the maximum floods that have occurred in different basins during the periods of their record. This means that each basin has only one maximum flood value recorded which has the connotation of probable maximum flood. Therefore, its probability distribution cannot be constructed, even though it should have a very low probability of occurrence. In order to further ensure that the design flood does not exceed the recorded maximum flood, an enveloping is developed.

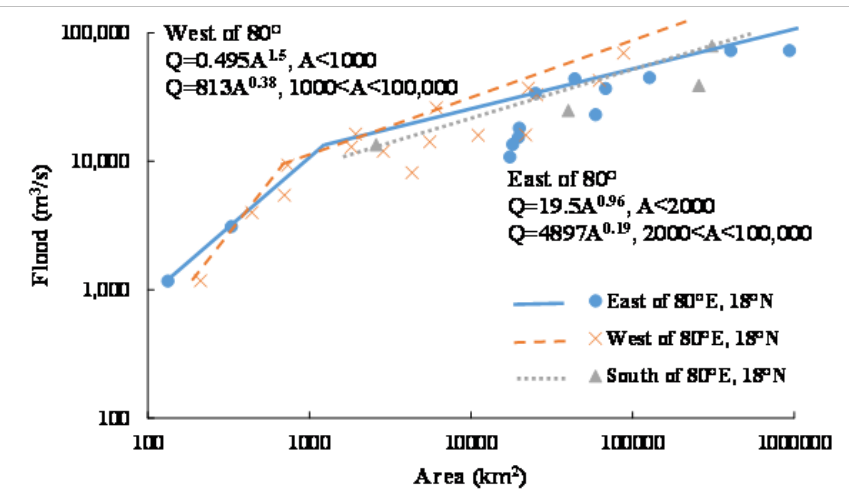

Figure 4 Enveloping curves of the 3 meteorology homogeneous zones off India.

\section{Flood peak area relationships}

The maximum flood discharge $\mathrm{Q}$ from a catchment area $\mathrm{A}$ is given by the formula as

$\mathrm{Q}=\mathrm{kA} \mathrm{A}^{\mathrm{n}}$
Enveloping curves of the three regions in India are given by the following equations:

a. For river catchments in the region located west of $80^{\circ} \mathrm{E}$ and north of $18^{\circ} \mathrm{N}$

$$
\begin{aligned}
& \left.Q=0.495 A^{1.5} \text { (For drainage catchments under } 1000 \mathrm{~km}^{2}\right) \\
& \left.Q=813 A^{0.38} \text { (For drainage catchments over } 1000 \mathrm{~km}^{2}\right)
\end{aligned}
$$

b. For river catchments in the region located east of $800 \mathrm{E}$ and north of $180 \mathrm{~N}$

$$
\begin{aligned}
& Q=19.5 A^{0.96} \text { (For drainage catchments under 2000km²) } \\
& Q=4897 A^{0.19} \text { (For drainage catchments over 2000km²) }
\end{aligned}
$$

c. For river catchments in the region located south of $18^{\circ} \mathrm{N}$

$$
Q=735 A^{0.37} \text { (For drainage catchments over } 1000 \mathrm{~km}^{2} \text { ) }
$$

\section{Conclusion}

Designs of dams and flood control structures require estimates of maximum flood discharges from river catchments. At those river sites where the flood data are meager, the envelope curve obtained by plotting the highest floods versus the drainage area can be used for estimating flood discharges. Using flood data of Indian rivers, Kanwar Sain and Karpov in 1967 developed two enveloping curves one to suit the catchments of south India and other for northern \& central India. These enveloping curves are old and moreover the recent floods lie above the enveloping curves. Thus, there is a need for a fresh study of envelope curves for the highest floods observed after the year 1967. Using the recent observed flood data, enveloping curves of the highest floods for the three different meteorologically homogeneous zones, namely rivers in the region located east of $80^{\circ} \mathrm{E}$ and north of $18^{\circ} \mathrm{N}$; rivers in the region located west of $80^{\circ} \mathrm{E}$ and north of $18^{\circ} \mathrm{N}$ and rivers in the region located south of $18^{\circ} \mathrm{N}$, have been determined. Envelope curves thus obtained are useful in getting preliminary flood estimates. If equations are fitted to these enveloping curves, they provide empirical flood formulae of the type $Q=f(A)$.

\section{Acknowledgment}

None.

\section{Conflict of interest}

None.

\section{References}

1. Dhar ON, Rakhecha PR. A review of hydrometeorological studies of Indian rainfall. Proc second World Congress on water resources. 1975;3:449-462.

2. Parthasarathy B. Inter annual and long-term variability of Indian summer monsoon rainfall. Proc Indian Acad Sci (Earth planet Sci). 1984;93(4):371-385.

3. CWC (Central Water Commission). National register of large dams, Dam safety organization New Delhi, India; 1990. p. 1-207.

4. WMO (World Meteorological Organization). Manual on estimation of probable maximum precipitation (PMP). WMO 2009;1045:1-291.

5. Mutreja KN. Applied hydrology. India: Mc Graw Hill; 1986. p. 1-959. 
6. CWC (Central Water Commission). Estimation of design flood recommended procedures. Ministry of Irrigation \& Power. India; 1972. p. $1-130$.

7. Kale VS. Long period fluctuations in monsoon floods in the Deccan peninsula India. J Geol Soc of India. 1999;53:5-15.

8. Rakhecha PP. Highest floods in India. Int Sym on Extraordinary floods. IAHS publ. 2002;271:167-172.

9. Rodier JA, Roche M. World Catalogue of maximum observed floods. USA: IAHS Press; 1984. p. 1-374.

10. Rakhecha PR, Kulkarni AK, Mandal BN, et al. Homogeneous zones of heavy rainfall of 1-day duration over India. Theor Appl Climatol. 1990;41(4):213-219.

11. Clark C, Rakhecha PR. Areal PMP distribution of one-day to three day duration over India. Meteorol. 2002:399-406.

12. Rakhecha PR, Singh VP. Applied Hydrometeorology. India: Capital Publishing Company; 2009. p. 1-384.
13. Pisharoty PR, Asnani GC. Rainfall around monsoon depressions over India. Indian J Meteor Geophys. 1957;8:1-6.

14. Rakhecha PR, Mandal BN, Kulkarni AK, et al. Estimation of Probable Maximum Precipitation for catchments of Eastern India by a generalized method. Theo Appl Climatol. 1995;51(1-2):67-74.

15. Rakhecha PR, Mandal BN, Kulkarni AK, et al. A hydrometeorological study of May 1943 rainstorm over Tamil Nadu. A historical event in the pre-monsoon season. Hydrology J of IAH. 1992;15:65-73.

16. Rakhecha PR, Mandal BN, Kulkarni AK, et al. A hydrometeorological analysis of the severe rainstorm of 20-22 September 1900 over the Gangetic West Bengal 1993. J Advances in Atmos Sciences. 1993;10(1):113-120.

17. IITM (Indian Institute of Tropical Meteorology). Severe rainstorms of India atlas. India: IITM Publ; 1994.

18. Rao KL. India's water wealth. India: Orient longman; 1975. p. 1- 255. 